\section{Prior History of Learning Disabilities Reye's Syndrome Survivors}

\author{
Ellen J. Quart, PhD, William M. Cruickshank, PhD \\ and Ashok Sarnaik, MB, BS
}

Twenty-six children, ages nine-18, who had recovered from Reye's syndrome were tested for possible memory deficits. In reviewing school histories, an unexpected finding was the disproportionately high number of students who were Learning Disabled before contracting Reye's syndrome. Seven of the children had been receiving special education services for being Learning Disabled and another two were viewed by their schools as being hyperactive. This is 10 times the expected incident rate. This group of Learning Disabled students did not score significantly worse on any measure than did the other children who had Reye's syndrome.

$T^{T}$ he data reported here constitute only a fraction of a much larger study (Quart, 1984). Two unexpected findings, however, deserve special attention and are abstracted from the major investigation.

Reye's syndrome (RS) strikes previously healthy children of all ages. The highest attack rate is in suburban and rural youngsters between the ages of 5 and 15 (Nelson, Sullivan-Bolyae, Marks, Morens, Schonberger, 1979). Although RS is characterized as a winter illness, cases are reported throughout the year, usually occurring in epidemic fashion. This is because most cases of RS are preceded by a viral infection, commonly due to influenza $\mathrm{A}, \mathrm{B}$, and varicella (chicken pox). The four commonly observed clinical prodromes are upper respiratory infection, chicken pox, gastroenteritis, and influenza-like ailment. Often the child seems to be recovering uneventfully when he/she deteriorates into the typical RS characteristics: vomiting, disorientation, lethargy, personality changes, and a decrease in the level of consciousness. Despite refinement of treatment methods leading to an increased survival rate, its etiology and pathogenesis remain obscure.

Efforts to establish the cause of RS have centered around three groups of factors: (1) viruses, (2) exogenous and endogenous toxins, and (3) susceptible hosts. Crocker and Ozere (1978) and Manz and Colon (1982) agree that the cause is not likely to be a single toxin or virus, but that there may be a genetic predisposition to RS which could be triggered by a virus, a toxin, or a combination of the two.

Physiologically, Reye's syndrome has characteristics in common with other types of diffuse insults that result in memory is impaired following diffuse though the literature does not agree on the type of memory deficit most affected, there is convincing evidence that memory is impaired following diffiuse brain injuries such as Korsakoff syndrome (see Victor, Adams \& Collins, 1971; Mair, Warrington, \& Weiskrantz, 1979) and closed head injuries (see Brooks, 1976, 1972; Smith, 1961, 1968, 1981). Moreover, specific localities in the brain that greatly influence memory are vulnerable to damage with RS. Over years of research, Milner has established the importance of the medial temporal lobe area in memory function $(1964,1966$, 1968, 1969, 1974). Under increased intracranial pressure, as is the case with RS, one might expect that the temporal lobes are more vulnerable to sustaining damage. But memory had not been specifically tested with this group. The psychological and neuropsychological research that has been done on RS survivors is very limited. Since it is a syndrome that is just beginning to be investigated, many questions remain unanswered. These early investigations have mainly looked at the general intellectual levels of RS survivors relative to age and coma level (e.g., Davidson, Willoughby, O'Tuama, Swisher, \& Benjamins, 1978; Shaywitz, Cohen, Cohen, Mikkelson,
Morowitz, Eberhardt, \& Shaywitz, 1980). The prior school histories of these youngsters are also an area that has been overlooked.

One of the most important considerations to make in trying to assess the influence of a particular neurological insult is to determine if the individual learns, behaves, or functions differently then he/she did before; or if he/she achieves as well as he/she would have, had the insult not occurred. In other words, an assessment of premorbid capacities is of utmost importance. In an effort to take this into account, the following measures have been included in this research design; (1) a parent questionnaire which seeks to obtain data and history from the parents regarding school or home, and (2) the Peabody Picture Vocabularly Test (PPVT) (Dunn, 1965) as a rough measure of premorbid IQ based on receptive vocabulary.

\section{TESTING PROCEDURE}

\section{Wechsler Memory Scale}

Each testing session began with an administration of the Wechsler Memory Scale (Form I). (Wechsler, 1948) For children under the age of 10 , the childrens' stories, developed by Taylor and McGlone (1979) were substituted for the adult stories. A slight modification of Wechsler's directions was used for the stories (Kimura \& McGlone, 1979). The Logical Memory, Visual Reproduction, and Associate Learning subtests were administered again for delayed recall at the end of the session (approximately 50 minutes later). Children were then asked to copy the designs in order to separate perceptual problems from those of retention.

\section{Peabody Picture Vocabulary Test}

The Peabody Picture Vocabulary Test (Form A) was next administered to all subjects in accordance with the procedure described in the manual; i.e. the student is shown a series of cards, each containing four drawings. The child is asked to point or verbally respond to the picture that depicits a word the examiner says. 


\section{Depth of Processing Tests}

Children were first given a memory for faces test. The superficial cue or question was "Is the person male or female?" and the deeper question was "Do you think the person is nice or not nice?" This test was followed by a memory for words test. With this test, the superficial question was "Is the word printed in all capital letters or all small letters?" and the deeper question was "Is it something alive or not alive?" The student was instructed to read the word out loud and if he/she did not know the word, the examiner would read it. There were a total of 30 stimulus cards for each test. The students were required to mark their answers on an answer sheet. Then after each series of stimulus cards, the student was shown a series of 30 pairs of faces (or words) and asked to mark on the answer sheet, which he/she had seen before. Special care was taken to avoid any effects of position (in time) and any effects due to easy or hard to remember words or faces.

\section{Test of Facial Recognition}

To ensure that errors on the memory for faces test were not due to an inability on the part of the student ot discriminate between faces, the Test of Facial Recognition (Form SL) (Benton, Van Allen, Hamsher, \& Levin, 1978) was given.

All tests to both groups were administered by the first author.

\section{Parent Questionnaire}

Preliminary findings (in examining patient records at Children's Hospital of Michigan) indicated that 18 out of 39 patients had a prior history of "learning problems." It was unknown whether the schools had made this diagnosis or whether only the parents felt this was the case. Therefore, each parent was asked to fill out a questionnaire while his/her child was being tested or to complete it at home and return it at his/her leisure.

This questionnaire specifically addressed school experiences before and after having RS. In order for a child to be put into the "LD group" in this study, he/she had to have been certified Learning Disabled (LD) by the schools before contracting RS. All the students in this group had received special education services as established by the State of Michigan for their learning disability.

Included in the questionnaire was also an information page. It asked years of education of the parents and their profession. This information was used to match for SES with the Control group.

\section{SUBJECTS}

\section{Reye's Syndrome Group}

All RS subjects in this research were children who had been treated for RS at Children's Hospital of Michigan in Detroit. Diagnosis was made according to the hospital's protocol on Reye's syndrome, and treatment was also consistent with that protocol. In addition, all patients were treated by Dr. Ashok Sarnaik (director of the Intensive Care Unit) or Dr. Gregory Preston (his assistant). All patients currently between the ages of 7 and 18 , admitted since the last change in treatment plan (1977), and diagnosed as reaching at least a stage $I$, were contacted by Dr. Sarnaik.

Twenty-six children who had recovered from RS were tested between March and July of 1983. Table 1 shows the distribution among the years 1978 to 1983 by RS stage and age range. None of the children tested was considered to have a seizure disorder (although some had experienced seizures while in coma). Only one child was on medication (Ritalin for hyperactivity). ${ }^{1}$ One child was black and twenty-five were white.

\section{Control Group}

All subjects in this group were taken from the Ann Arbor Public Schools, Ann Arbor, Michigan. A list of needed ages and percentile ranks (based on results of the PPVT from the RS group) was given to the director of research. The resultant computer printout was sent to designated schools. The researcher met with principals or counselors at those buildings.

'The parents reported their child had always been hyperactive, even before having RS at the age of 4 years. She was put on Ritalin at age 6 years in the hopes of improving her school behavior.

${ }^{2} \mathrm{Six}$ IQ points is the expected variation for the PPVT (Dyer, 1983)
With a knowledge of the students and their families, they made recommendations for selection based on a lack of learning or emotional problems, race, parent profession and years of education. As many as four children were sometimes tested in order to get a match. Only students who scored within 6 IQ points $^{2}$ on the PPVT to their prospective match were used as a control. ${ }^{3}$

\section{RESULTS}

Earlier it was stated that two unexpected results developed within the data. First, information from the parent questionnaire regarding the students' performance prior to contracting RS disclosed a high number of children with learning disabilities. Seven out of the twenty-six students in the RS group had received special education services for learning disabilities before they had RS. An additional two students were previously (and are presently) viewed by their schools as being hyperactive. One is now on Ritalin and the second child was referred for testing by the school (before he had RS) but the parents refused to consent to testing.

Despite a history of learning disabilities or hyperactivity, these students did not perform significantly poorer than the rest of the RS group as indicated by two-tailed student $t$-tests. Table 2 describes these findings.

A second unexpected finding was the large number of left-handed subjects in the RS group. Six children in the RS group were left handed as compared to one child in the control group. Springer and Deutsch (1981) report that, according to cross-cultural studies, the incidence of left-handedness is around 10\% (although Spiegler and Yeni-Komshian [1983] more recently report an incidence of $13.8 \%$ among university students). The incidence of left-handedness in the RS population under study is $23.1 \%$. Based on an assumption that the incidence in the general population is $10 \%$, the probability of getting 6 or more out

\footnotetext{
${ }^{3}$ Prospective match means that they were of the same race, were within 6 months of age of each other, had the same SES, and were near the same percentile ranks of each other on verbal measures.

${ }^{2}$ This study was supported in part by a grant from the National Reye's Syndrome Foundation.
} 


\begin{tabular}{|c|c|c|c|c|c|c|c|c|}
\hline \multirow[b]{2}{*}{$\begin{array}{c}\text { RS } \\
\text { Stage }\end{array}$} & \multicolumn{8}{|c|}{$\begin{array}{l}\text { Table } 1 \\
\text { Frequency Distribution Between } 1977 \text { and } 1983 \text { by } \\
\text { Peak Reye's Syndrome Stage and Age Range } \\
\end{array}$} \\
\hline & $\mathrm{n}$ & 1977 & 1978 & 1979 & 1980 & 1981 & 1982 & 1983 \\
\hline 1 & 2 & & 1 & 1 & & & & \\
\hline ॥ & 7 & 1 & & 3 & 3 & & & \\
\hline III & 4 & & 1 & & 2 & & & 1 \\
\hline IV & 11 & 1 & 1 & 3 & 4 & 1 & & 1 \\
\hline \multirow[t]{2}{*}{$\mathrm{V}$} & 2 & & & 1 & 1 & & & \\
\hline & $\mathrm{N}=26$ & 2 & 3 & 8 & 10 & 1 & 0 & 2 \\
\hline $\begin{array}{l}\text { Age at } \\
\text { onset }\end{array}$ & & 3-5 & $4-10$ & $3-14$ & $6-15$ & 8 & & $10-15$ \\
\hline
\end{tabular}

of 26 is .25 .

Next, it seemed logical to look at this group of left-handed subjects and investigate their performance as compared to the right-handed RS children. Table 3 reports the results of various two-tailed student $t$ tests. For the left-handers in the
RS group, their MQ was significantly lower, $(p<.01, d f=24)$ as were the tests of Logical Memory, memory for faces total errors $(p<.05$, $d f=24)$, and the number of errors they made on faces that had been deeply cued $(p<$ $.005, d f=24)$.

\section{DISCUSSION}

These data, albeit derived from a small RS population, indicate that a surprising number of children in the RS group were diagnosed as being Learning Disabled before they had RS. These authors believe that Learning Disabilities have a neurological basis. The possibility exists that there is something about the brains (or livers) of LD children (and possibly left-handers) that makes them more at risk to develop Reye's syndrome.

Among the children examined in this study, the incidence of children who were LD before they had RS is 10 times the incidence rate of $L D$ in the region where they live. Several issues need to be discussed relative to this: (1) how representative the samples are; and (2) what this might mean for the LD population in general. Each issue will be considered separately.

It is assumed that the RS group included in this study is a representative sample of the larger group of children

Table 2

Descriptive Differences Between Students in the RS Group Who Have A History of School Difficulty Compared to Those Who Do Not

\begin{tabular}{|c|c|c|c|c|c|c|}
\hline \multirow[b]{2}{*}{ Variable } & \multirow[b]{2}{*}{ Group } & \multirow[b]{2}{*}{$\mathrm{N}$} & \multirow[b]{2}{*}{ Minimum } & \multirow[b]{2}{*}{ Maximum } & \multicolumn{2}{|c|}{ Std. } \\
\hline & & & & & Mean & Error \\
\hline \multirow[t]{3}{*}{$\mathrm{IQ}$} & $\begin{array}{l}\text { History of } \\
\text { Learning Disabilities } \\
\text { No Prior History } \\
\text { of Learning }\end{array}$ & 7 & 83 & 121 & 101.86 & 5.22 \\
\hline & $\begin{array}{l}\text { Disabilities } \\
\text { History of }\end{array}$ & 17 & 88 & 138 & $114.59^{\star \star \star \star}$ & 3.39 \\
\hline & hyperactivity & 2 & 95 & 107 & 101.00 & 6.02 \\
\hline \multirow[t]{3}{*}{$M Q$} & $\begin{array}{l}\text { History of } \\
\text { Learning Disabilities } \\
\text { No prior history } \\
\text { of Learning }\end{array}$ & 7 & 70 & 100 & 90.14 & 3.68 \\
\hline & $\begin{array}{l}\text { Disabilities } \\
\text { History of }\end{array}$ & 17 & 79 & 122 & $99.35^{\star \star}$ & 2.73 \\
\hline & hyperactivity & 2 & 89 & 90 & 89.50 & .50 \\
\hline \multirow[t]{3}{*}{$\begin{array}{l}\text { MQ-IQ } \\
\text { Difference }\end{array}$} & $\begin{array}{l}\text { History of } \\
\text { Learning Disabilities }\end{array}$ & 7 & -27.00 & 10.00 & -11.71 & 5.49 \\
\hline & $\begin{array}{l}\text { No prior history } \\
\text { of Learning Disabilities } \\
\text { History of }\end{array}$ & 17 & -38.00 & 8.00 & $-15.77^{\star}$ & 3.18 \\
\hline & hyperactivity & 2 & -17.00 & -6.00 & -11.50 & 5.51 \\
\hline
\end{tabular}

*Student $T$ test, $d f=22, p=.5111$

** Student $T$ test, $d f=22, p=.0719$

***Student $T$ test, $d f=22, p=.0541$ 
Table 3

Student T-Tests Comparison of Left and Right-Handed Subjects From the RS Group

\begin{tabular}{|c|c|c|c|c|c|}
\hline Variable & Group & $\mathrm{N}$ & $\begin{array}{l}\text { Mean } \pm \\
\text { Std. Error }\end{array}$ & $\begin{array}{c}\mathrm{T}- \\
\text { Statistic }\end{array}$ & Significance \\
\hline IQ & $\begin{array}{l}\text { left-handed } \\
\text { right-handed }\end{array}$ & $\begin{array}{r}6 \\
20\end{array}$ & $\begin{array}{l}103.67 \pm 4.93 \\
112.05 \pm 3.35\end{array}$ & 1.25 & NS \\
\hline$M Q$ & $\begin{array}{l}\text { left-handed } \\
\text { right-handed }\end{array}$ & $\begin{array}{r}6 \\
20\end{array}$ & $\begin{array}{c}85.50 \pm 3.71 \\
99.30 \pm 2.18\end{array}$ & 3.08 & .01 \\
\hline $\begin{array}{l}\text { Logical } \\
\text { Memory } \\
\text { (Immediate) }\end{array}$ & $\begin{array}{l}\text { left-handed } \\
\text { right-handed }\end{array}$ & $\begin{array}{r}6 \\
20\end{array}$ & $\begin{array}{l}5.70 \pm .66 \\
9.18 \pm .68\end{array}$ & 2.67 & .05 \\
\hline $\begin{array}{l}\text { Logical } \\
\text { Memory } \\
\text { (Delayed) }\end{array}$ & $\begin{array}{l}\text { left-handed } \\
\text { right-handed }\end{array}$ & $\begin{array}{r}6 \\
20\end{array}$ & $\begin{array}{l}3.47 \pm .60 \\
7.09 \pm .79\end{array}$ & 2.43 & .05 \\
\hline $\begin{array}{l}\text { Memory for Faces } \\
\text { (Total Errors) }\end{array}$ & $\begin{array}{l}\text { left-handed } \\
\text { right-handed }\end{array}$ & $\begin{array}{r}6 \\
20 \\
\end{array}$ & $\begin{array}{r}917 \pm 1.14 \\
5.45 \pm .72 \\
\end{array}$ & 2.55 & .05 \\
\hline $\begin{array}{l}\text { Memory for Faces } \\
\text { (Errors From } \\
\text { Superficial Cues) }\end{array}$ & $\begin{array}{l}\text { left-handed } \\
\text { right-handed }\end{array}$ & $\begin{array}{r}6 \\
20\end{array}$ & $\begin{array}{l}4.17 \pm .54 \\
3.20 \pm .47\end{array}$ & 1.06 & NS \\
\hline $\begin{array}{l}\text { Memory for Faces } \\
\text { (Errors From } \\
\text { Deep Cues) } \\
\end{array}$ & $\begin{array}{l}\text { left-handed } \\
\text { right-handed }\end{array}$ & $\begin{array}{r}6 \\
20\end{array}$ & $\begin{array}{l}5.00 \pm .93 \\
2.25 \pm .36\end{array}$ & 3.32 & .005 \\
\hline $\begin{array}{l}\text { Memory for Words } \\
\text { (Total Errors) }\end{array}$ & $\begin{array}{l}\text { left-handed } \\
\text { right-handed }\end{array}$ & $\begin{array}{r}6 \\
20 \\
\end{array}$ & $\begin{array}{l}2.33 \pm .56 \\
1.90 \pm .30 \\
\end{array}$ & .69 & NS \\
\hline $\begin{array}{l}\text { Memory for Words } \\
\text { (Errors From } \\
\text { Superficial Cues) }\end{array}$ & $\begin{array}{l}\text { left-handed } \\
\text { right-handed }\end{array}$ & $\begin{array}{r}6 \\
20\end{array}$ & $\begin{array}{r}1.00 \pm .36 \\
.75 \pm .14\end{array}$ & .77 & NS \\
\hline $\begin{array}{l}\text { Memory for Words } \\
\text { (Errors From } \\
\text { Deep Cues) }\end{array}$ & $\begin{array}{l}\text { left-handed } \\
\text { right-handed }\end{array}$ & $\begin{array}{r}6 \\
20\end{array}$ & $\begin{array}{l}1.33 \pm 49 \\
1.15 \pm .20\end{array}$ & .41 & NS \\
\hline
\end{tabular}

who have recovered from $\mathrm{RS}$. This is because all RS survivors were included in this study who were treated at Children's Hospital of Michigan between 1977 and 1983 that were able to be reached by phone or letter except two (who did not wish to participate). With a 93\% positive response rate, one cannot say that more parents of LD children responded because they wanted their child tested or were more concerned about their child. There is a question whether the group of LD students in this study are representative of LD students in the general population, however. Since RS is mainly a white (for children over 1 year of age), suburban and rural disease, the LD students in this group are not representative of LD children in general. Another point is that the statement that $27 \%$ of this RS population was LD before they had the disease is based on survivorsnot on all children who contracted RS between 1977 and 1983.

These statistics may have profound implications for LD children. If this sample is representative of all RS survivors, then within the group of children who survive $\mathrm{RS}$, one would expect 10 times as many children to have been LD before getting RS than in the general population. This is not meant to imply causality, but perhaps there is something in common between these two groups. There seem to be a variety of factors that lead to RS in children, and children also become LD for a variety of reasons. It may be that among these contributing factors there exists a common characteristic (e.g. a biochemical abnormality or a genetic predisposition).

In other words, these statistics mean that LD children (especially white, suburban and rural) are 10 times more likely to get RS than children overall. This is assuming that the proportion of LD children who died from RS is the same as for the survivors. If there were no LD children among those who died, one could still say that the LD child is at least 8 times more likely to get RS than the random child.

Due to small sample size, it is not necessarily the case that this high proportion (.27) will be maintained in the general population. By calculating the tail of a binomial distribution, it can be seen that with a fair amount of certainty $(p<$ .05) This is still more than 4 times the expected rate.

However, being Learning Disabled originally does not appear to prejudice their outcome. The LD group did 
not perform significantly worse on any measure than did the other children who had RS.

One subgroup of students who did perform poorly as a group was the left-handers. They had significantly poorer scores on the Logical Memory subtest and the memory for faces test. There was also a high percentage of left-handers in the RS population $(23 \%)$. Although this was not significantly different from the expected population value of $10 \%(r=.26)$, with a larger population it might prove to be. The incidence of left-handers is very high in other populations with known brain damage (mentally retarded, learning disabled, epileptics). Reitan (1974) reported that 10 out of the 29 LD children in his brain-damaged population were left-handed. Bakan and Reed (1973) contend that all left-handedness is a result of trauma at birth. This is an extreme view, but one cannot ignore the elevated incidence of left-handedness among children in special clinical populations. It is a provocative possibility that left-handers might be more at risk to contract RS and that their outcome is worse than right-handers.

\section{CONCLUSIONS}

The results of this study indicate that the incidence of RS among LD children is 10 times what is expected. However, their outcome is not significantly worse than the other children who contracted RS.

Left-handed children who have had RS scored significantly worse than their right-handed peers on their MQ. They did particularly badly on remembering auditory verbal material.

Left-handed children who have had RS made significantly more errors on remembering faces and did not benefit from increasing the depth of processing.

\section{RECOMMENDATIONS FOR FURTHER RESEARCH}

Questions were raised in this study regarding left-handedness and a prior history of learning disabilities. Further in- vestigation is needed in order to determine if the incidence rates observed here extend to children in other states who both have had RS and to children who did not survive RS. If similar findings result, investigating why LD students or left-handers are more likely to get RS will be a challenging area of research.

\section{REFERENCES}

Bakan, G.D., \& Read, P. Handedness and birth stress. Neuropsychologia, 1973, 11, 363-366.

Benton, A.L., Van Allen, M.W., Hamsher, K. de S., \& Levin, H.S. Test of Facial Recognition, Form SL. Oxford University Press, 200 Madison Avenue, New York, New York, 10016.

Brooks, D.N. Memory and head injury. Journal of Nervous and Mental Disease, 1972, 155(5), 350-355.

Brooks, D.N. Wechsler Memory Scale performance and its relationship to brain damage after severe closed head injury. Journal of Neurology, Neurosurgery, and Psychiatry, 1976, 39, 593-601.

Crocker, J.F.S., \& Ozere, R.L. The incidence and etiology of Reye's syndrome in eastern Canada. In J.F.S. Crocker (Ed.), Reye's syndrome II. New York: Grune \& Stratton, 1979.

Davidson, P.W., Willoughby, L.A., O'Tuama, L.A., Swisher, C.N., \& Benjamins, D. Neurological and intellectual sequelae of Reye's syndrome. American Journal of Mental Deficiencies, 1978, 82, 535-541.

Dunn, L.M. Peabody Picture Vocabulary Test. Circle Pines, Minnesota: Annual Guidance Service, Inc., 1965.

Dyer, C. Personal communication, April 9, 1983.

Kimura, D., \& McGlone, J. (Eds.), Neuropsychological test manual. London, Ontario: D.F. Consultants, 1979.

Mair, W.G.P., Warrington, E.K., \& Weiskrantz, L. Memory disorders in Korsakoff's psychosis. A neuropathological and neuropsychological investigation of two cases. Brain, 1979, 102, 749-783.

Manz, H.J., \& Colon, A.R. Neuropathology, pathogenesis, \& neuropsychiatric sequelae of Reye's syndrome. Journal of Neurological Sciences, 1982, 53, 377-395.

Milner, B. Some effects of frontal lobectomy in man. In J. Warren \& $K$. Akert (Eds.), The frontal granular cortex and behavior, New York: McGraw Hill, 1964, 313.

Milner, B. Amnesia following operation on the temporal lobes. In $C$. Whitty \& $O$. Zangwill (Eds.), Amnesia. London: Butterworth \& Co., 1966, 109-133.

Milner, B. Residual intellectual and memory deficits after head injury. In A.E. Walker. W.F. Caveness \& $H$. Critchley (Eds), The late effects of head injury, Springfield: Charles Thomas, 1969.

Milner, B. In F.O. Schmitt \& F.G. Worden (Eds.). The neurosciences: Third study program, Cam- bridge: MIT Press, 1974, 75-85.

Milner, B. Carkin, S., \& Teuber, H.L. Further analysis of the hippocampal amnesic syndrome. Neuropsychologia, 1968, 6, 267-282.

Nelson, D.B., Sullivan-Bolyai, J.Z., Marks, J.S., Morens, D.M., \& Schonberger, L. Reye's syndrome: An epidemiologic assessment based on national surveillance 1977-1978 and a population based study in Ohio 1973-1977. In J.F.S. Croker (Ed.), Reye's syndrome II. New York: Grune \& Stratton, 1979.

Quart, E.J. Memory and attention in children recovered from Reye's syndrome. Doctoral dissertation, The University of Michigan, 1984.

Reitan, R.M. Psychological effects of cerebral lesions in children of early school age. In $R$. Reitan \& L. Davison (Eds.), Clinical neuropsychology: Current status and applications. New York: John Wiley \& Sons, 1974.

Shaywitz, S.E., Cohen, P.M., Cohen, D.J., Mikkelson, E., Morositz, G., Eberhardt, N.C., \& Shaywitz, B.A. Longterm consequences of Reye's syndrome: A siblingmatched controlled study of neurologic cognitive, academic and psychiatric function in Reye's syndrome. Journal of Pediatrics, $1982,100,41-46$.

Smith, A. Duration of impaired consciousness as an index of severity in closed head injuries. Diseases of the Nervous System, 1961, 22, 69-74.

Smith, A. Neuropsychological aspects of learning disorders. Learning Disorders, 1968, 3, 61-91.

Smith, A. Principals underlying human brain functions in neuropsychological sequelae of different neuropathological processes. In S. Filskov \& T. Boll Handbook of Clinical Neuropsychology. New York: John Wiley \& Sons, 1981.

Spiegler, B.J. \& Yeni-Kamshian, G.M. Incidence of left-handed writing in a college population with reference to family patterns of hand preference. Neuropsychologia, 1983, 21(6), 651-659.

Springer, S., \& Deutsch, G. Left brain, right brain. San Francisco: W.H. Freeman and Company, 1981.

Taylor, L., \& McGlone, J. Children's stories for testing LTM. In D. Kimura \& J. McGlone (Eds.), Neuropsychological test manual. London, Ontario: D.K. Consultants, 1979.

Victor, M., Adams, R.D., \& Collins, G.M. The Wernicke-Korsakoff syndrome. Philadelphia: F.A. Davis, 1971 .

Wechsler, D., \& Stone, C., Wechsler Memory Scale. New York: The Psychological Corporation, 1948.

\section{ABOUT THE ATHORS}

Ellen J. Quart, PhD, is a Teacher Consultant for the Ann Arbor Public Schools. Mail can be addressed to 1645 Miller Avenue, Ann Arbor. Michigan, 48103.

William M. Cruickshank, PhD, is a Professor of Child and Family Health at the University of Michigan.

Ashok Sarnarik, $M B, B S$, is the director of the Intensive Care Unit at Children's Hospital Michigan. 